\title{
DFT Calculation on the Electronic Structure and Optical Properties of $\operatorname{In}_{x} G a_{1-x} N$ Alloy Semiconductors
}

\author{
Xuewen WANG*, Wenwen LIU, Chunxue ZHAI, Jiangni YUN, Zhiyong ZHANG
}

School of Information Science and Technology, Northwest University, Xi'an City, China, 710127

crossref http://dx.doi.org/10.5755/j01.ms.26.2.21569

Received 04 September 2018; accepted 15 December 2018

\begin{abstract}
Using the density functional theory (DFT) of the first principle and Generalized gradient approximation method, the electronic structures and optical properties of the $\operatorname{In}_{x} \mathrm{Ga}_{1-\mathrm{x}} \mathrm{N}$ crystals with different $\mathrm{x}(\mathrm{x}=0.25,0.5,0.75,1)$ have been calculated in this paper. The influence of the electronic structure on the properties has been analyzed. Then the influence of doping quantity on the characteristics has been summarized, which also indicates the trend of complex dielectric function, absorption spectrum and transitivity. With the increase of $x$, the computational result shows that the optical band gap (i.e.Eg) of the $\mathrm{In}_{\mathrm{x}} \mathrm{Ga}_{1-\mathrm{x}} \mathrm{N}$ crystal tends to be narrow, then the absorption spectrum shifts to the low-energy direction. And the Fermi energy slightly moves to the bottom of conduction band which would cause the growth of conductivity by increasing $\mathrm{x}$. In a word, the $\operatorname{In}_{\mathrm{x}} \mathrm{Ga}_{1-\mathrm{x}} \mathrm{N}$ compound can be achieved theoretically the adjustable $\mathrm{Eg}$ and photoelectric performance with $\mathrm{x}$, which will be used in making various optoelectronic devices including solar cell and sensors.

Keywords: $\mathrm{In}_{\mathrm{x}} \mathrm{Ga}_{1-\mathrm{x}} \mathrm{N}$ crystal, electronic structure, optoelectronic property, density functional theory.
\end{abstract}

\section{INTRODUCTION}

Due to the rapid development of microelectronics technology, InN-based semiconductor materials such as binary InN or ternary InGaN crystals that belong to directgap semiconductors have received much attention. They become one hotspot of the third generation semiconductors, which have the favorable electronic and optical properties including its high carrier mobility, higher breakdown voltage, high speed and a considerable range of emissions in the visible spectrum [1]. They can be also applied to many devices such as power electronics, sensors, high-efficiency solar cells, light emitting diodes at relatively long-visible wavelengths (LVW) and high electron mobility transistors (HEMTs) [1-3].

Many scholars have studied InGaN. Firstly, they focused on that $\mathrm{InN}$ and $\operatorname{In}_{\mathrm{x}} \mathrm{Ga}_{1-\mathrm{x}} \mathrm{N}$ materials can be prepared in different growth technologies with different In and Ga raw materials $[4,5]$. Paying attention to study on InGaN quantum well [6] and growth of $\mathrm{n}$ - polar InGaN alloy films on high quality $\mathrm{n}-$ polar GaN templates [7]. Secondly, the band gap of InGaN alloy has been calculated [8]. Then Indium content in $\operatorname{In}_{\mathrm{x}} \mathrm{Ga}_{1-\mathrm{x}} \mathrm{N}$ quantum dots can change the performance of laser diode (LD) [9] and indium (In) content can change InGaN crystal quality and optical properties [10]. However, the first principle study on the electronic structure and optical properties of the $\operatorname{In}_{\mathrm{x}} \mathrm{Ga}_{1-\mathrm{x}} \mathrm{N}$ alloy are rarely reported. In this paper, the electronic structure and optical properties of $\operatorname{In}_{\mathrm{x}} \mathrm{Ga}_{1-\mathrm{x}} \mathrm{N}$ alloy were discussed by firstprinciples calculations based on the density functional theory (DFT). Also the photoelectric properties of the $\mathrm{In}_{\mathrm{x}} \mathrm{Ga}_{1-\mathrm{x}} \mathrm{N}$ alloy with different Indium content were discussed in details, which provide an important theoretical basis for the research photoelectric devices and sensors.

\section{THEORETICAL MODEL AND CALCULA- TION METHOD}

The crystal model of $\mathrm{InN}$ and $\operatorname{In}_{\mathrm{x}} \mathrm{Ga}_{1-\mathrm{x}} \mathrm{N}$ on the calculation is hexagonal wurtzite structure like GaN crystal, whose bulk phase is part of $\mathrm{P} 63 \mathrm{mc}$ space group, the symmetry is $C_{6 V}^{4}$ [11]. A part of the unicellular model of $\mathrm{GaN}$ is firstly created and optimized to the stable single-cell structure, and the $2 \times 2 \times 2$ super cellular model containing $16 \mathrm{Ga}$ atoms and $16 \mathrm{~N}$ atoms is constructed with a stable single cell model. In order to calculate and study electronic structure and optical performance of $\mathrm{In}_{\mathrm{x}} \mathrm{Ga}_{1-\mathrm{x}} \mathrm{N}$ in different concentration of In, a uniform distribution model of In atoms in $\mathrm{GaN}$ is selected under each $\mathrm{x}$, and the $2 \times 2 \times 2$ super-cell models with $50 \%$ contents of In are shown in Fig. 1, where then $\mathrm{N}$ atoms are blue, $\mathrm{Ga}$ atoms are gray and In atoms are pink, and the lattice constants of InN super-cell model are $\mathrm{a}=0.3523 \mathrm{~nm}, \mathrm{~b}=0.3523 \mathrm{~nm}, \mathrm{c}=0.5688 \mathrm{~nm}$, $\gamma=120^{\circ}, \alpha=\beta=90^{\circ}, \quad$ wherein $\mathrm{c} / \mathrm{a}=1.614$.

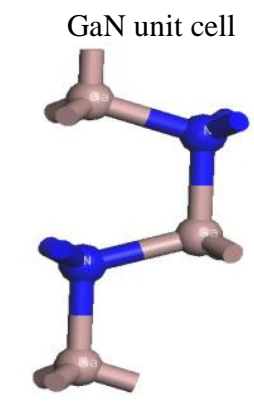

a

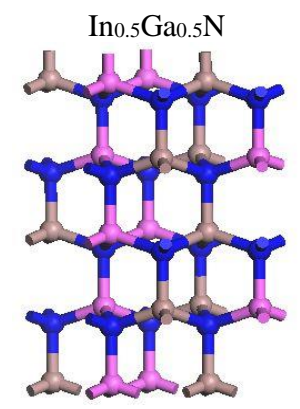

b
Fig. 1. The unit cell of wurtzite GaN and super cell models of $\mathrm{In}_{\mathrm{x}} \mathrm{Ga}_{1-\mathrm{x}} \mathrm{N}$. In the figure, Blue: $\mathrm{N}$ atoms, Gray: Ga atoms and Pink: In atoms (in colour online)

\footnotetext{
* Corresponding author. Tel.: +13488466766.

E-mail address: wangxuew@nwu.edu.cn (X. Wang)
} 
The unit cell of wurtzite $\mathrm{GaN}$ and super cell models of $\mathrm{In}_{0.5} \mathrm{Ga}_{0.5} \mathrm{~N}$ are shown in Fig. 1, all In atoms are substitutional for $\mathrm{Ga}$ atoms in $\mathrm{GaN}$ and are distributed in the model as evenly as possible, which models are as similar as possible to alloy mode in principle.

In this paper, MS CASTEP module of software Materials-studio 8.0 is used for the theoretical calculation in order to predict the electronic structures and photoelectric properties of real $\operatorname{In}_{\mathrm{x}} \mathrm{Ga}_{1-\mathrm{x}} \mathrm{N}$ materials. It is based on the plane-wave pseudo potential method from the DFT (Density Functional Theory) of ab initio quantum mechanics and GGA-PW91 function is used in the calculation [12]. Under the allowable situation of the hardware resources and the determinate convergence of system energy at the level of the quasi- complete fundamental wave. The k point selection of $\mathrm{In}_{\mathrm{x}} \mathrm{Ga}_{1-\mathrm{x}} \mathrm{N}$ is $4 \times 4 \times 2$, the cutoff energy is selected to be $310 \mathrm{eV}$. The force convergence accuracy on each atom should be less than $2.0 \times 10^{-5} \mathrm{eV} /$ atom and internal stress convergence accuracy should be less than $0.1 \mathrm{GPa}$.

\section{THE ANALYSIS OF CALCUATION RESULTS}

\subsection{Electrical structure analysis of $\operatorname{In}_{x} G_{a}-x$ crystals}

\subsubsection{Lattice constants}

In this paper, we used the optimized GaN super cell model and replaced $\mathrm{Ga}$ atoms in $\mathrm{GaN}$ with In atoms. Then they were distributed evenly in the $\operatorname{In}_{x} \mathrm{Ga}_{1-\mathrm{x}} \mathrm{N}$ model in proportion and the GGAPW91 was used to calculate. The calculation results show that the lattice constants of $\mathrm{In}_{\mathrm{x}} \mathrm{Ga}_{1-\mathrm{x}} \mathrm{N}$ crystals can change with the increase of $\mathrm{x}$, as listed in Table 1 . When $\mathrm{x}=0$ and $\mathrm{x}=1$, the computed data of the lattice constants are different from the experimental values, for example $\mathrm{a}_{\mathrm{GaN}}=\mathrm{b}_{\mathrm{GaN}}=3.189 \AA, \mathrm{c}_{\mathrm{GaN}}=5.185 \AA$ [13], $\quad \mathrm{a}_{\text {InN }}=\mathrm{b}_{\text {InN }}=3.548 \AA, \quad c_{\text {InN }}=5.760 \AA \quad[14] . \quad$ The computed data of the lattice constants are slightly larger than experimental values which is caused by GGA. The difference of $a_{G a N}$ is $1.25 \%$ from the practical value, the one of $c_{G a N}$ is $1.48 \%$, one of $c_{G a N}\left(a_{G a N}\right)^{-1}$ is $0.23 \%$, one of $a_{I n N}$ is $2.23 \%$, one of $c_{\text {InN }}$ is $1.94 \%$, and one of $c_{\text {InN }}\left(a_{\text {InN }}\right)^{-1}$ is $0.276 \%$. The results are in the admitted error range since the calculation method is the same as literature [14]. From Table 1, when In replaces of Ga, the values of both a and $c$ in $\operatorname{In}_{x} \mathrm{Ga}_{1-\mathrm{x}} \mathrm{N}$ trend to increasing along with $\mathrm{x}$, meanwhile the volume of cell also shows an increasing trend, which can abide by Vegard's Law. It is very easy to understand the radius of $\mathrm{In}^{3+}$ of $0.08 \mathrm{~nm}$ is bigger than one of $\mathrm{Ga}^{3+}$ of $0.62 \AA$.

Table 1. The lattice constants of $\operatorname{In}_{x} \mathrm{Ga}_{1-\mathrm{x}} \mathrm{N}(\mathrm{x}=0,0.25,0.5,0.75$, 1) crystals

\begin{tabular}{|c|c|c|c|c|c|}
\hline & $\mathrm{x}=0$ & $\mathrm{x}=0.25$ & $\mathrm{x}=0.5$ & $\mathrm{x}=0.75$ & $\mathrm{x}=1$ \\
\hline $\mathrm{a}=\mathrm{b}(\AA)$ & 3.229 & 3.334 & 3.449 & 3.529 & 3.627 \\
\hline $\mathrm{c}(\AA)$ & 5.262 & 5.408 & 5.527 & 5.709 & 5.872 \\
\hline
\end{tabular}

\subsubsection{Energy band and electronic density of states}

In the calculation of electrical properties of $\operatorname{In}_{\mathrm{x}} \mathrm{Ga}_{1-\mathrm{x}} \mathrm{N}$ crystals, the band structures of $\operatorname{In}_{\mathrm{x}} \mathrm{Ga}_{1-\mathrm{x}} \mathrm{N}$ with different $\mathrm{x}$ are calculated, which are similar to one of the $\operatorname{In}_{0.5} \mathrm{Ga}_{0.5} \mathrm{~N}$ as shown $\mathrm{In}_{8} \mathrm{Ga}_{8} \mathrm{~N}_{16}$ in Fig. 2. $\mathrm{In}_{0.5} \mathrm{Ga}_{0.5} \mathrm{~N}$ are situated on the same position in $\mathrm{k}$ space that the top of conduction band and the vertex of valence band, which shows that the $\operatorname{In}_{0.5} \mathrm{Ga}_{0.5} \mathrm{~N}$ crystal belongs to the direct band gap semiconductor, and the band-gap width is $0.539 \mathrm{eV}$. The values of optical band gap $\left(E_{g}\right)$ while $x$ varies into $0,0.25,0.5,0.75$ and 1 are $1.621,1.165,0.539,0.361$ and $0.321 \mathrm{eV}$ respectively. Compared with the experiment values $(3.4 \mathrm{eV})$ of $\mathrm{GaN}$ and $(0.70 \mathrm{eV})$ of InN, we plus the scissors operator in order to make up the gap $(1.621 \mathrm{eV})$ into $3.4 \mathrm{eV}$, or $0.321 \mathrm{eV}$ into $0.7 \mathrm{eV}$, so that the calculated $\mathrm{E}_{\mathrm{g}}$ is more accurate. The $1.131 \mathrm{eV}$ in Fig. 2 is a modified value from the calculated one $(0.539 \mathrm{eV})$ of the $\operatorname{In}_{0.5} \mathrm{Ga}_{0.5} \mathrm{~N}$ and a scissors difference of $0.592 \mathrm{eV}$ [15]. The reason that the theoretically calculated value one is much less than the experimental one is what the exchange-correlation energy used in the GGA of MS software is an exchange-correlation functional primary approximation. Due to the adoption of GGA exchange function so that the band-gap width is undervalued. However, it cannot affect the analysis of the $\mathrm{E}_{\mathrm{g}}$ change trend of the similar structure crystals with different $\mathrm{x}$ under the same calculation conditions, and the data above shows that $E_{g}$ can be reduced with the increase of $x$ in $\operatorname{In}_{x} G a_{1-x} N$. With the increasing of indium component, the bottom of the conduction band moves slightly towards the low energy direction, which is called a red shift phenomenon [16].

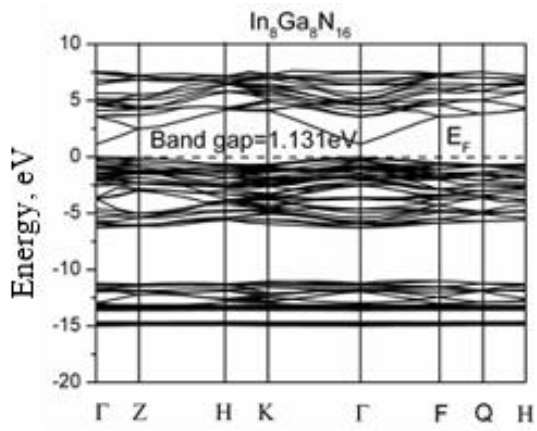

Fig. 2. Band structure of $\operatorname{In} 0.5 \mathrm{Ga} 0.5 \mathrm{~N}$

The density of states (DOS) of $\operatorname{In}_{0.5} \mathrm{Ga}_{0.5} \mathrm{~N}$ is shown in Fig. 3 a. It follows that the electron energy bands include one conduction band of $1.6 \sim 6 \mathrm{eV}$ and two valence bands in the left which are separately called as the lower valence band of $-17 \mathrm{ev} \sim-11 \mathrm{eV}$ and the upper valence band of $-7.5 \mathrm{eV} \sim 0 \mathrm{eV}$. Fig. $3 \mathrm{~b}$ shows the partial density of states of different atoms, where s, p, d and f represent electronic sub-shells respectively. It shown that the lower valence band of $\mathrm{In}_{0.5} \mathrm{Ga}_{0.5} \mathrm{~N}$ is resulted from Ga3d In $4 \mathrm{~d}$ and $\mathrm{N} 2 \mathrm{~s}$. The conduction band consists of the $4 \mathrm{~s}$ and $4 \mathrm{p}$ states of $\mathrm{Ga}$ atoms, $5 \mathrm{~s}$ and $5 \mathrm{p}$ states of In atoms and $2 \mathrm{~s}$ and $2 \mathrm{p}$ states of $\mathrm{N}$ atoms. The peak in $-13 \mathrm{eV}$ is generated by the $\mathrm{Ga} 3 \mathrm{~d}$ state and the In $4 \mathrm{~d}$ state, while the peak in $-16 \mathrm{eV}$ is mostly provided by the $\mathrm{N} 2 \mathrm{~s}$.

Being compared to the electronic DOS of GaN, the relative positions of various peaks move to low energy are about $0.753 \mathrm{eV}$, which is due to that optical band gap narrows down. The intensity of the peaks in the conduction band doesn't change, and the intensity of the peaks in $-11.5 \mathrm{eV}$ and $-6 \mathrm{eV}$ falls down which results from In atoms. At the same time, the Fermi level moves slightly to the bottom of the conduction band, which indicates that the 
electrical conductibility of the crystal enhances to some extent.

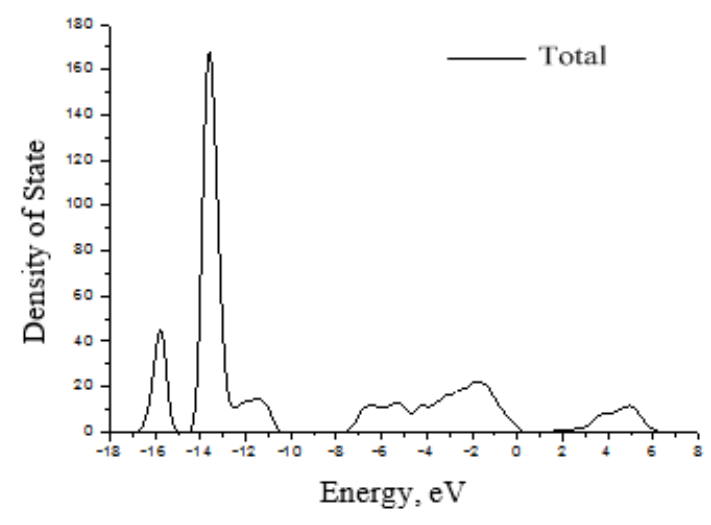

a

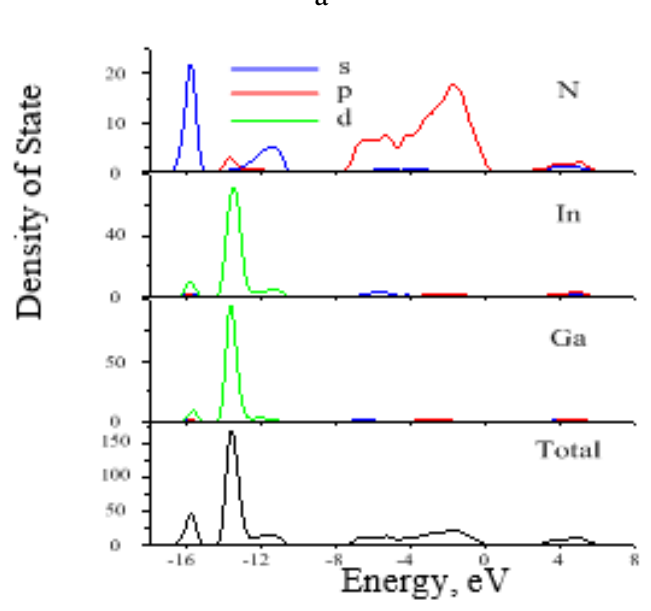

$\mathrm{b}$

Fig. 3. Density of states of $\operatorname{In}_{0.5} \mathrm{Ga} 0.5 \mathrm{~N}$ : a - electronic density of states; $b$ - partial density of states

\subsection{The discuss of calculation characteristics of $\mathrm{In}_{\mathrm{x}} \mathrm{Ga}_{1-\mathrm{x}} \mathrm{N}$ crystals}

While a light with wavelength $\lambda$ and frequency $\omega$ propagates in $\mathrm{In}_{\mathrm{x}} \mathrm{Ga}_{1-\mathrm{x}} \mathrm{N}$ crystal, the complex refractive index $n^{*}(\omega)$ of the crystal is equal to the value that is $n(\omega)+i n_{\mathrm{k}}(\omega)$. The $n(\omega)$ and $n_{\mathrm{k}}(\omega)$ are the real part and the imaginary part (namely extinction coefficient) of the complex refractive index In, respectively. The absorption coefficient $(\alpha(\omega))$ of the crystal is in proportion to $\left(n_{\mathrm{k}}(\omega)\right.$ and the optical frequency $(\omega)$ seeing in Eq. 1. In consideration of that the complex dielectric constant $\left(\varepsilon_{1}+i \varepsilon_{2}\right)$ of the crystal can generally represent the macroscopic optical response of the crystal and may make known the luminous mechanism of the electron transitions between energy levels of the crystal microcosmically. The $\varepsilon_{2}, \varepsilon_{1}$ can be deduced in accordance with the definition of a direct transition probability and Kramers-Kroning dispersion relation. So the $\alpha(\omega), n(\omega)$ and $n_{\mathrm{k}}(\omega)$ optical parameters can be inferred from $\varepsilon_{2}(\omega)$ and $\varepsilon_{1}(\omega)$, and the reflection coefficient $(R(\omega))$ is only determined by $n(\omega), n_{\mathrm{k}}(\omega)$ and transmission coefficient $(T(\omega))$ parameters. Wherein, Eq. 2 - Eq. 7 are derived from reference [17].

$\alpha(\omega)=\frac{4 \pi}{\lambda} n_{k}(\omega)=\frac{2}{c} n_{k}(\omega) \cdot \omega ;$

$$
\varepsilon_{2}=\frac{\pi e^{2}}{\varepsilon_{0} \mathrm{~m}^{2} \omega^{2}} \sum_{\mathrm{V}, \mathrm{C}} \int_{B Z} \frac{2 d K}{(2 \pi)^{3}}\left|a \cdot M_{C V}(K)\right|^{2} \delta\left[E_{c}(K)-E_{V}(K)-h \omega\right]
$$

$$
\varepsilon_{1}=1+\frac{2 e}{\varepsilon_{0} \mathrm{~m}^{2}} \sum_{\mathrm{V}, \mathrm{C}} \int_{B Z} \frac{2 d K}{(2 \pi)^{3}} \frac{\left|\vec{a} \cdot M_{V C}(K)\right|^{2}}{\left[E_{C}(K)-E_{V}(K)\right] / h} \cdot \frac{1}{\left[E_{C}(K)-E_{V}(K)\right]^{2} / h^{2}-\omega^{2}}
$$

$n(\omega)=\sqrt{\frac{\left(\varepsilon_{1}(\omega)\right)^{2}+\left(\varepsilon_{2}(\omega)\right)^{2}+\varepsilon_{1}(\omega)}{2}} ;$

$n_{k}(\omega)=\sqrt{\frac{\left(\varepsilon_{1}(\omega)\right)^{2}+\left(\varepsilon_{2}(\omega)\right)^{2}-\varepsilon_{1}(\omega)}{2}} ;$

$R(\omega)=\frac{(n(\omega)-1)^{2}+\left(n_{k}(\omega)\right)^{2}}{(n(\omega)+1)^{2}+\left(n_{k}(\omega)\right)^{2}}$

$T(\omega)=1-\overline{\alpha(\omega)}-\overline{R(\omega)}$.

Wherein, $\mathrm{C}$ and $\mathrm{V}$ mean the valence band and conduction band, BZ is the first Brillouin zone, respectively. $K$ is the reciprocal lattice vector, $h$ is the Planck constant, $\left|\mathrm{a} M_{V C}(k)\right|$ is the matrix elements of the momentum transition, $E_{c}(k)$ is the conduction band of intrinsic energy levels and $E_{V}(k)$ is valence band, $\overline{\alpha(\omega)}$ or $\overline{R(\omega)}$ is the value that $\alpha(\omega)$ or $R(\omega)$ is normalized to, respectively.

\subsubsection{Complex dielectric function}

After calculation, the relation curves of the complex dielectric function including imaginary part $\left(\varepsilon_{2}\right)$ and real part $\left(\varepsilon_{1}\right)$ of $\operatorname{In}_{\mathrm{x}} \mathrm{Ga}_{1-\mathrm{x}} \mathrm{N}$ crystal with incident photon energy or angular frequency $(\omega)$ are shown in Fig. 4.

In Fig. 4 a, five curves from up to down represent $\mathrm{GaN}$, $\mathrm{In}_{0.25} \mathrm{Ga}_{0.75} \mathrm{~N}, \mathrm{In}_{0.5} \mathrm{Ga}_{0.5} \mathrm{~N}, \mathrm{In}_{0.75} \mathrm{Ga}_{0.25} \mathrm{~N}$, InN, respectively. It can show that the number of peaks appearing in each curve is similar. The all peak positions shift to low energy direction in different extent with the increase of $x$. The result shows that the optical gap of $\operatorname{In}_{\mathrm{x}} \mathrm{Ga}_{1-\mathrm{x}} \mathrm{N}$ crystals constantly reduces and the lattice constant increases gradually with the increase of $\mathrm{x}$. The peaks positions appearing in the $\varepsilon_{2}$ curve are closely related to the electron transition between energy levels. For example, $\varepsilon_{2}$ curve of $\mathrm{GaN}$, in Table 2, when $\mathrm{x}=0$, the peak at $4.2 \mathrm{eV}$ is the direct transition from valence band to conduction band of $\mathrm{N} 3 \mathrm{p}$ state. The peaks at $7.5 \mathrm{eV}$, $9.8 \mathrm{eV}$ and $12.2 \mathrm{eV}$ in $\varepsilon_{2}$ curve of $\mathrm{GaN}$ are caused by the electron transitions between the valence bands whose electrons is the Ga $3 \mathrm{~d}$ state and N 2s state of lower valence band or the N 2p state of upper valence band. In Fig. 4 b, the static dielectric constant value of the observation material is the longitudinal coordinate value of the $0 \mathrm{eV}$ photon energy. The static dielectric constant is $3.97,4.63,5.59,6.28$ and 6.47 while $\mathrm{x}$ is $0,0.25,0.5,0.75$ and 1 respectively, which will be increased gradually with the increase of $x$ component. With the increase of In component $\mathrm{x}$, the static dielectric constant increases gradually. This is because the band gap value gradually decreases or narrows, electrons need only a small amount of energy can be excited from the top of the valence band transition to the top of the conduction band, it is easy to be polarized, so the value of the dielectric constant will gradually increase [18]. The peak positions appearing in $\varepsilon_{1}$ curve are gradually moving towards the low energy state, which is consistent with the 
change trend of the imaginary part $\varepsilon_{2}$ of the complex dielectric function.

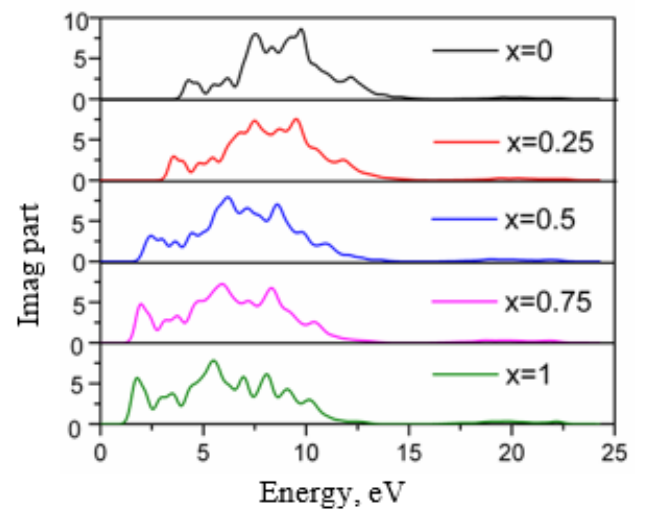

a

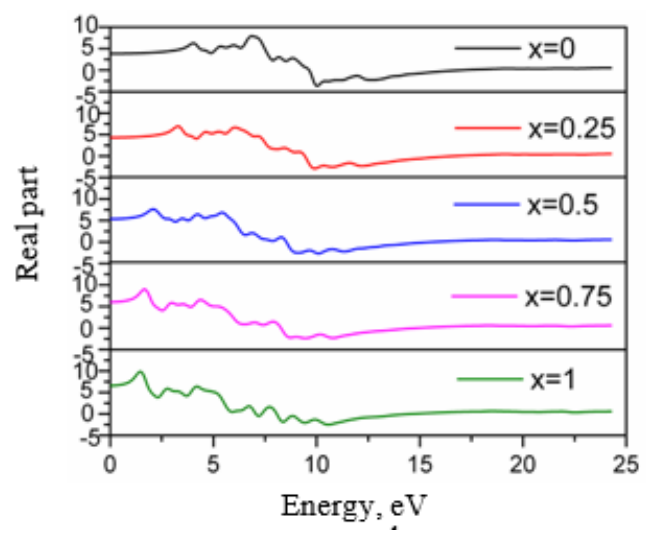

b

Fig. 4. Relation curves of complex dielectric function of $\operatorname{In}_{\mathrm{x}} \mathrm{Ga}{ }_{1-\mathrm{x}} \mathrm{N}$ crystals and incident photon energy: $\mathrm{a}-\varepsilon_{2}$ in different $\mathrm{x}$; $\mathrm{b}-\varepsilon_{1}$ in different $\mathrm{x}$

Table 2. In the imaginary part of the complex dielectric function of $\operatorname{In}_{x} \mathrm{Ga}_{1-\mathrm{x}} \mathrm{N}(\mathrm{x}=0,0.25,0.5,0.75,1)$, there are five strong peaks

\begin{tabular}{|l|c|c|c|c|c|}
\hline Unit, $\mathrm{eV}$ & 1 & 2 & 3 & 4 & 5 \\
\hline $\mathrm{GaN}$ & 4.2 & 7.5 & 9.8 & 12.2 & 19.6 \\
\hline $\mathrm{In}_{0.25} \mathrm{Al}_{0.75} \mathrm{~N}$ & 3.2 & 7.3 & 9.5 & 11.9 & 18.7 \\
\hline $\mathrm{In}_{0.5} \mathrm{Al}_{0.5} \mathrm{~N}$ & 2.5 & 6.7 & 8.9 & 10.8 & 18 \\
\hline $\mathrm{In}_{0.75} \mathrm{Al}_{0.25} \mathrm{~N}$ & 2.3 & 5.9 & 8.3 & 10.5 & 17.5 \\
\hline $\mathrm{InN}$ & 2.1 & 5.5 & 7.7 & 10.1 & 17.0 \\
\hline
\end{tabular}

\subsubsection{Optical absorption and transmission}

The optical absorption curves and the cut-off edge of absorption curves of $\operatorname{In}_{x} \mathrm{Ga}_{1-\mathrm{x}} \mathrm{N}(\mathrm{x}=0,0.25,0.5,0.75,1)$ are calculated theoretically are presented in Fig. 5. It can be found from the comparison of Fig. 5 a and Fig. 4 a that the peak positions are approach to the ones of the $\varepsilon_{2}$ dielectric function while the In density has great difference. The absorption spectrum reaches the strongest peak at about $9.5 \mathrm{eV}$, which can be caused by the transitions of $\mathrm{Ga} 3 \mathrm{~d}$ state and $\mathrm{N} 2 \mathrm{p}$ state shown in Fig. 3, consistent with reference [19]. The cut-off edge of absorption curves of $\operatorname{In}_{\mathrm{x}} \mathrm{Ga}_{1 \mathrm{x}} \mathrm{N}$ $(\mathrm{x}=0,0.25,0.5,0.75,1)$ models from Fig. $5 \mathrm{~b}$ can be gotten as $364 \mathrm{~nm}, 460 \mathrm{~nm}, 835 \mathrm{~nm}, 1087 \mathrm{~nm}$ and $1402 \mathrm{~nm}$, that is similar to the result of reference [20,21], so it is show that the simulation method is feasible.
It is seen from Fig. 5 a that the absorption curves of $\mathrm{In}_{\mathrm{x}} \mathrm{Ga}_{1-\mathrm{x}} \mathrm{N}$ gradually shift to long wave direction with the increase of $x$. It explains the absorption wavelength occurs "red shift" phenomenon to the infrared band, which results in presenting a narrow absorption band with the small intensity in long wavelength range, covering the visible to infrared wavelength range. So people can use the characteristics of $\operatorname{In}_{\mathrm{x}} \mathrm{Ga}_{1-\mathrm{x}} \mathrm{N}$ materials to design infrared optoelectronic devices.

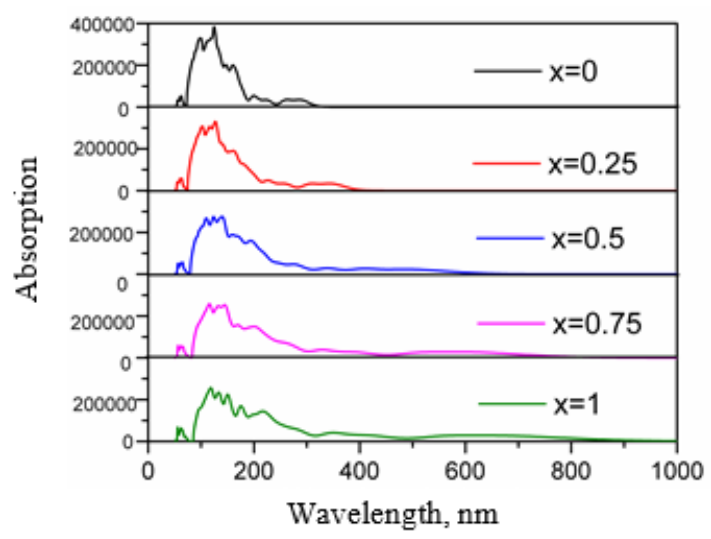

a

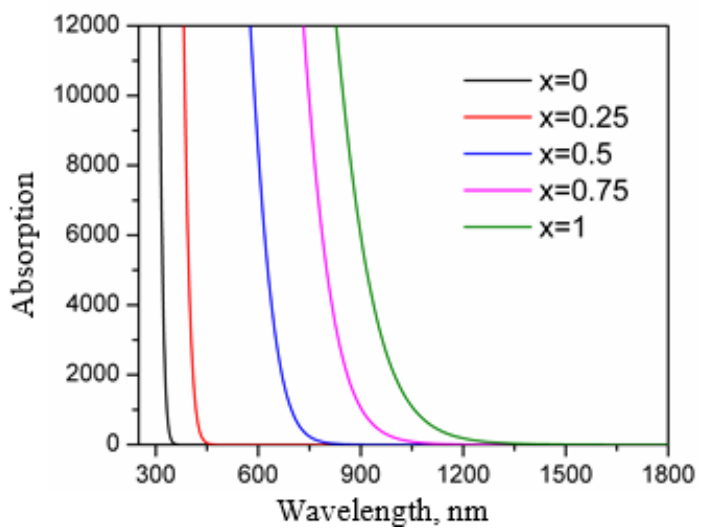

b

Fig. 5. The absorption spectrum and its cut-off edge of $\operatorname{In}_{\mathrm{x}} \mathrm{Ga}_{1-\mathrm{x}} \mathrm{N}$ : $\mathrm{a}$-the absorption spectrum; b-cut off edge graph of absorption spectrum

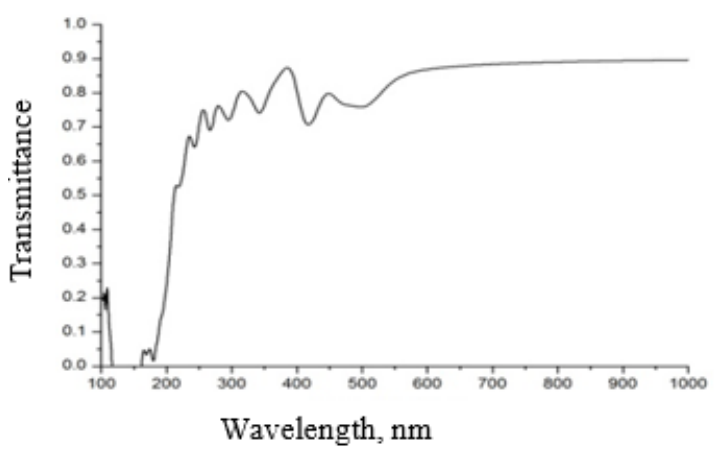

Fig. 6. Optical transmittance of intrinsic $\mathrm{In}_{0.5} \mathrm{Ga}_{0.5} \mathrm{~N}$ crystal

The transmittance $T$ can be calculated by using seven Formula above, and Fig. 6 shows one of the $\operatorname{~}_{0.5} \mathrm{Ga}_{0.5} \mathrm{~N}$ with $\mathrm{x}=0.5$. We can find out that the transmittance change is irreguar before $560 \mathrm{~nm}$, then transmittance gradually achieves smooth, the transmission rate decreases $88 \%$ that 
is smaller than $93 \%$ of intrinsic GaN. The wavelength range of absorption and transmission of $\operatorname{In}_{\mathrm{x}} \mathrm{Ga}_{1-\mathrm{x}} \mathrm{N}$ includes sunlight, infrared light and ultraviolet light. The stable transmission wavelength is longer, consistent with the changing trend of the experimental data in reference [22], it can be applied to a wide wavelength solar cell, a photoelectric device, and a sensor.

\section{CONCLUSIONS}

In this paper, we first constructed the supercell GaN crystal and calculated the optimized photoelectric characteristics, then build the super-cell $\operatorname{In}_{\mathrm{x}} \mathrm{Ga}_{1-\mathrm{x}} \mathrm{N}$ with the different density of In, then the electrical structure and photoelectric characteristics were calculated. The results found, with the increase of In concentration, both the values of $a$ and $c$ of $\operatorname{In}_{x} \mathrm{Ga}_{1-\mathrm{x}} \mathrm{N}$ enlarge, $\operatorname{In}_{\mathrm{x}} \mathrm{Ga}_{1-\mathrm{x}} \mathrm{N}$ is direct gap semiconductor, and optical band gap $\left(\mathrm{E}_{\mathrm{g}}\right)$ decreases, and the conductivity becomes strong. From the calculation results of the complex dielectric function, we know that the peak positions in the imaginary part shift to low energy direction, and the static dielectric function of the real part is increased. Due to the increase of In concentration, the absorption spectrum shifted to low energy region and this cut-off edge shifts to the long wavelength direction, the transmittance change worse. In brief, it can adjust that photoelectric property by changing the ratio of In atom to $\mathrm{Ga}$ atom in the $\mathrm{In}_{\mathrm{x}} \mathrm{Ga}_{1-\mathrm{x}} \mathrm{N}$ alloy semiconductor. The conductive performance of $\operatorname{In}_{x} \mathrm{Ga}_{1-x} \mathrm{~N}$ enhances with the increase of In concentration, and the absorption spectrum shows "red shift" phenomenon. This experiment meets the development trend of InN-based materials and can be advantageous to the development application in optoelectronic device and sensor fields.

\section{Acknowledgments}

This work was supported by the National Natural Science Foundation of China (No. 61405159), the National Natural Science Foundation of China (No. 61076002) and the Natural Science Foundation of Education Commission of Shaanxi Province (Grant No. 2012JK848).

\section{REFERENCES}

1. Bagavath, C., Nasi, L., Kumar, J. Investigations on the Nanostructures of $\mathrm{GaN}, \mathrm{InN}$ and $\mathrm{In}_{\mathrm{x}} \mathrm{Ga}_{1-\mathrm{x}} \mathrm{N}$ Materials Science in Semiconductor Processing 49 2016: pp. 61-67. https://doi.org/10.1016/j.mssp.2016.03.032

2. Hwang, J., Lee, K., Jin, S.K., Lee, C.R., Lee, I.H., Lee, K. Manipulation on the Optical Properties of InGaN/GaN Light Emitting Diodes by Adopting InN Layer Journal of Crystal Growth 370 2013: pp. 109-113. https://doi.org/10.1016/j.jcrysgro.2012.08.049

3. Liu, G., Ju, W., Lu, Y., Zhao, G., Gu, C., Liu, C. Two Dimensional Electron Gas Mobility Limited by Scattering of quantum dots with Indium Composition Transition Region in Quantum Wells Physica E: Low-dimensional Systems and Nanostructures 52 2013: pp. 150-154. https://doi.org/10.1016/j.physe.2013.04.009

4. Cho, Y.J., Sadofev, S., Fernándezgarrido, S., Calarco, R., Riechert, H., Galazka, Z. Impact of Substrate Nitridation on the Growth of InN on In2O3 (111) by Plasma-assisted
Molecular Beam Epitaxy Applied Surface Science 369

2016: pp. $159-162$.

https://doi.org/10.1016/j.apsusc.2016.01.268

5. Li, X., Zhao, D.G., Yang, J., Jiang, D.S., Liu, Z.S., Chen, P. Influence of InGaN Growth Rate on the Localization States and Optical Properties of InGaN/GaN Multiple Quantum Wells Superlattices and Microstructures 97 2016: pp. 186-192. https://doi.org/10.1016/j.spmi.2016.06.023

6. Gorai, A., Mistry, A., Panda, S., Biswas, D. Inclusion of Indium, with Doping in the Barriers of $\mathrm{In}_{\mathrm{x}} \mathrm{Ga}_{1-\mathrm{x}} \mathrm{N} / \mathrm{In}_{\mathrm{x}} \mathrm{Ga} \mathrm{a}_{-\mathrm{x}} \mathrm{N}$ Quantum Wells Reveals Striking Modifications of the Emission Properties Wwth Current for Better Operation of leds Photonics and Nanostructures - Fundamentals and Applications 28 2018: pp. 70-74.

https://doi.org/10.1016/j.photonics.2017.11.010

7. Yang, F., Zhang, Y., Han, X., Li, P., Jiang, J. Huang, Z. Growth Parametric Study of N-polar InGaN Films by Metalorganic Chemical Vapor Deposition Superlattices and Microstructures 91 2016: pp. 259-268. https://doi.org/10.1016/j.spmi.2016.01.024

8. Dridi, Z., Bouhafs, B., Ruterana, P. First-principles Calculation of Structural and Electronic Properties of Wurtzite $\mathrm{Al}_{\mathrm{x}} \mathrm{Ga}_{1-\mathrm{x}} \mathrm{N}, \mathrm{In}_{\mathrm{x}} \mathrm{Ga}_{1-\mathrm{x}} \mathrm{N}$, and $\mathrm{In}_{\mathrm{x}} \mathrm{Al}_{1-\mathrm{x}} \mathrm{N}$ Random Alloys Physica Status Solidi (1) 2010: pp. 315-319. https://doi.org/10.1002/pssc.200390052

9. Liang. F., Zhao, D., Jiang, D., Liu, Z.,Improvement of Slope Efficiency of GaN-Based Blue Laser Diodes by Using Asymmetric MQW and $\operatorname{In}_{\mathrm{x}} \mathrm{Ga}_{1-\mathrm{x}} \mathrm{N}$ Lower Waveguide Journal of Alloys and Compounds 731 2018: pp. 243-247. https://doi.org/10.1016/j.jallcom.2017.09.328

10. Liu, J., Liang, H., Xia, X., Abbas, Q., Liu , Y., Anomalous Indium Incorporation and Optical Properties of High Indium Content InGaN Grown by MOCVD Journal of Alloys and Compounds 735 2018: pp. 1239-1244. https://doi.org/10.1016/j.jallcom.2017.11.248

11. Chadi, D.J. Special Points for Brillouin-zone Integrations Physical Review B Condensed Matter 16(4) 1977: pp. $5188-5192$. https://doi.org/10.1103/PhysRevB.16.1748

12. Usman, Z., Cao, C., Mahmood, T. Pressure Based Firstprinciples Study of the Electronic, Elastic, Optic and Phonon Properties of Zincblende InN Physica B Condensed Matter 430 (12) 2013: pp. $67-73$. https://doi.org/10.1016/j.physb.2013.07.031

13. Surender, S., $\quad$ Pradeep, S., Prabakaran, K., Sumithra, S.M., Singh, S., Baskar, K. The Role of Indium Composition on Thermo-electric Properties of InGaN/GaN Heterostructures Grown by Mocvd Journal of Alloys \& Compounds 734 2018: pp. $48-54$. https://doi.org/10.1016/j.jallcom.2017.10.293

14. Weihua, W., Guozhong, Z. 2012 Lattice Vibrations and Optical Properties of wurtzite InN in the Reststrahlen Region Physica B: Condensed Matter 407 (21) 2012: pp. $4313-4317$. https://doi.org/10.1016/j.physb.2012.07.024

15. Ross, A., Bezerra, S., Faraj, S., Yousefi, K., Fedor, H., Glavaris, S., 2008 First-principles Calculation of the Band Gap of $\mathrm{Al}_{\mathrm{x}} \mathrm{Ga}_{1-\mathrm{x}} \mathrm{N}$ and $\mathrm{In}_{\mathrm{x}} \mathrm{Ga}_{1-\mathrm{x}} \mathrm{N}$ Revista Mexicana De Física 54 (2) 2008: pp. $111-118$. https://doi.org/doi:10.1088/0034-4885/71/11/116501

16. Jenkins, D.W., Dow, J.D. Electronic Structures and Doping of InN, $\operatorname{In}_{\mathrm{x}} \mathrm{Ga}_{1-\mathrm{x}} \mathrm{N}$, and $\operatorname{In}_{\mathrm{x}} \mathrm{Al}_{1-\mathrm{x}} \mathrm{N}$ Physical Review $B \quad 39$ (5) 1989: pp. $3317-3329$. http://dx.doi.org/10.1103/PhysRevB.39.3317 
17. Peng, J., Mu, Y., Liu, P., Shen, X., Zhou, S. A New Magneto-optic Effect of Quasi-two-dimensional Conductors Journal of Physics: Condensed Matter 4 (2) 1992: pp. $525-529$

http://dx.doi.org/10.1088/0953-8984/4/2/019

18. Hori, M., Kano, K., Yamaguchi, T., Saito, Y., Araki, T., Nanishi, Y. Optical Properties of Inxga1 - xn with Entire Alloy Composition on Inn Buffer Layer Grown by Rf - mbe Physica Status Solidi 234 (3) 2015: pp. 750-754. http://dx.doi.org/10.1002/15213951(200212)234:3<750::AID-PSSB750>3.0.CO;2-K

19. Zhang, S., Shi, J., Zhang, M., Yang, M., Li, J. Firstprinciples Investigation on Optical Properties of $\mathrm{GaN}$ and InGaN Alloys Journal of Physics D Applied Physics 44 (49) 2011: pp. $495304-\mathrm{xxx}$.

http://dx.doi.org/10.1088/0022-3727/44/49/495304
20. Naser, M.A., Zaliman, S., Hashim, U. Investigation of the Absorption Coefficienr, Refractive Index, Energy Band gap, and Film Thickness for $\mathrm{Al}_{0.11} \mathrm{Ga} 0.89 \mathrm{~N}, \mathrm{Al}_{0.03} \mathrm{Ga} 0.97 \mathrm{~N}$, and $\mathrm{GaN}$ by Optical Transmission Method Nanoelectronics and Materials 2 (2) 2009: pp. 189-195.

21. Hori, M., Kano, K., Yamaguchi, T., Saito, Y., Araki, T., Nanishi, Y. Optical Properties of $\operatorname{In}_{x} \mathrm{Ga}_{1-\mathrm{x}} \mathrm{N}$ with Entire Alloy Composition on InN Buffer Layer Grown by RFMBE Physica Status Solidi 234 (3) 2015: pp. 750-754. http://dx.doi.org/10.1002/15213951(200212)234:3<750::AID-PSSB750>3.0.CO;2-K

22. Tuna Linhart, W.M., Lutsenko, E.V., Rzheutski, M.V., Yablonskii, G.P., Veal, T.D. Structural, Electrical and Optical Characterization of MOCVD Grown In-rich InGaN Layers Journal of Crystal Growth 358 2012: pp. 51-56. http://dx.doi.org/10.1016/j.jcrysgro.2012.07.040 